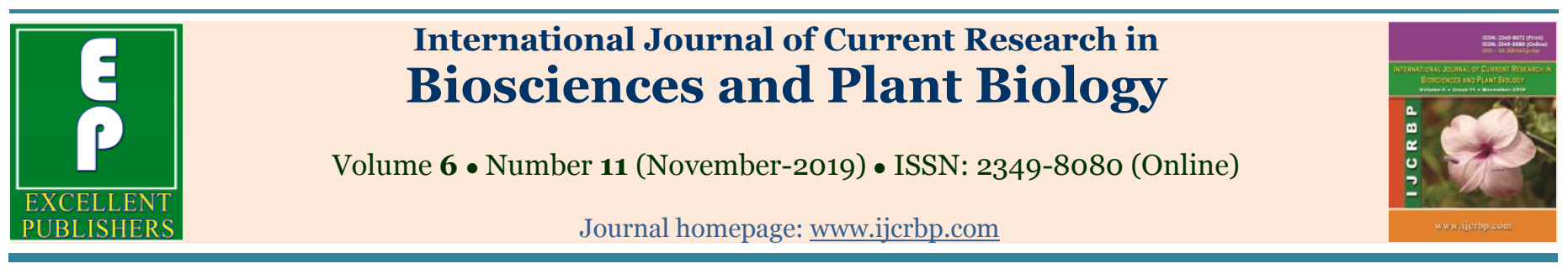

\title{
Tick infestation and haematocrit alteration of cattle in Boklé- Garoua (Northern Cameroon)
}

\author{
Samuel Abah",2,3*, Wade Abel3, Alexandre Michel Njan Nlôga², \\ Sevidzem Silas Lendzele 4,5, Abdoulmoumini Mamoudou6, Simon Dickmu3, \\ Rodrigue Simonet Poueme Namegni3, Yaya Aboubakar3, Andre Zoli6, \\ Ndamkou Christian3 and Abdoulkadiri Souley3
}

\author{
${ }^{1}$ Special Mission for Tse-Tse Fly Eradication, Ngaoundéré, Cameroon \\ ${ }^{2}$ Department of Biological Sciences, Faculty of Science, University of Ngaoundéré, Cameroon \\ 3Laboratoire National Veterinaire, LANAVET, Garoua, Cameroon \\ 4IRET, Department of Animal Biology, PO Box 13354, Libreville, Gabon \\ 5Ecole Doctorale des Grandes Ecoles (EDGE), Laboratoire d'Ecologie Vectorielle (LEV-IRET), \\ BP: 13354, Libreville, Gabon. \\ ${ }^{6}$ School of Veterinary Medicine and Sciences, University of Ngaoundéré, Cameroon \\ ${ }^{*}$ Corresponding author; e-mail: abadadaaba@yahoo.fr
}

\begin{tabular}{|c|c|}
\hline Article Info & ABSTRACT \\
\hline $\begin{array}{l}\text { Date of Acceptance: } \\
24 \text { September } 2019 \\
\text { Date of Publication: } \\
\text { o6 November } 2019\end{array}$ & $\begin{array}{l}\text { Ticks and Tick-Borne Diseases (TBDs) represent a scourge to livestock health and } \\
\text { production in Cameroon. Information on their ecology and impact on cattle in the } \\
\text { North region of Cameroon which is an important livestock zone of Cameroon is scanty, } \\
\text { reason why a cross sectional study in the rainy season was conducted from May to } \\
\text { September } 2015 \text { in the locality of Boklé-Garoua in the North region of Cameroon with }\end{array}$ \\
\hline Keywords & $\begin{array}{l}\text { the aim of ldentifying the different species of ticks and relate tick load with haematocrit. } \\
\text { Ticks were collected once a week from six adult cattle and identified using standard }\end{array}$ \\
\hline $\begin{array}{l}\text { Cattle } \\
\text { Haematocrit } \\
\text { Prevalence } \\
\text { Synamics } \\
\text { Ticks }\end{array}$ & $\begin{array}{l}\text { keys. In total, } 404 \text { ticks were collected and classified under Amblyomma variegatum, } \\
\text { Hyalomma truncatum, Rhipicephalus sanguineus and Rhipicephalus (Boophilus) } \\
\text { decoloratus. Hyalomma truncatum (50\%) was the most frequent species, } \\
\text { whileRhipicephalus sanguineus(1\%)was the least. There was a negative and statistically } \\
\text { non-significant( } \mathrm{r}=-\mathrm{O} \text {, } 170 \text {, p }>0.05) \text { correlation in mean tick load and haematocrit of } \\
\text { cattle.The results of this study indicate the occurrence of four species of ticks and their } \\
\text { negative but non-significant effect on haematocrit of cattle from the north region of } \\
\text { Cameroon. Studies on the diseases transmitted by these vectors are underway and will } \\
\text { indicate the impact and need for their control in Cameroon. }\end{array}$ \\
\hline
\end{tabular}

\section{Introduction}

Ticks are blood-sucking ectoparasites and represent one of the major constraints to livestock production in Cameroon. The North region of Cameroon is an important livestock zone of the country (MINEPIA, 2003). To augment animal production (meat, milk etc)in order to meetwith its national and international demands, it is imperative to fight against ticks and the diseases they transmit. The economic losses inflicted by TBDs is estimated at 30-40 \$USA per year (Lew- 
Tabor and Rodriguez Valle, 2016). Current reports indicate the occurrence of Rhipicephalus (Boophilus) microplusin Cameroon and reveal the neighbouring Nigeria as its possible source (Mebanga Sassaet al., 2014; Silatsa et al., 2019). This species is economically important worldwide partly because of its ablility to rapidly develope resistance to major chemical classes of acaricides (de La Fuente et al., 2007). It is common in west Africa (Yao-Acapovi et al., 2018; Diaha-Kouame et al., 2019), but few studies have reported its occurrence in central Africa (Mebanga Sassa et al., 2014; Silatsa et al., 2019). Although few reports already exist on the occurrence of ticks in North Cameroon (Mamoudou et al., 2015; Abah et al., 2017), there is need to update on its occurrence and impact on livestock. The presence of ticks and their co-existence with trypanosomes and TBDs in cattle in North and Adamawa regionsled to the alteration of their haematocrit (Mamoudou et al.,2015; Abdoulmoumini et al., 2017). To control ticks in rangelands, there is need to know their species composition, dynamics and impact, reason for which a study was conducted in the locality of
Boklé in Garoua in the North region of Cameroon to identify the different species of ticks on cattle as well as correlating tick burden and haematocrit.

\section{Materials and methods}

\section{Study area}

The survey was carried out at the Garoua National Veterinary Laboratory (LANAVET) animal farm, located in Bocklé village, found in Garoua III District of Benoue Division in the North Region of Cameroon. It is bordered to the north by river Benoue, to the south by the Sanguéré-Goumbai village, to the east by the Sanguéré Ngaoundéré village and to the west by the Djalingo village (Fig.1). LANAVET is $14 \mathrm{Km}$ from the town of Garoua on the Ngaoundéré-Garoua highway. The animals are kept in a semi-intensive husbandry system. The animals from thisresearch lab were chosen because they are kept solely for experimental purposes. The survey was conducted in the rainy (period with high tick numbers) season from May to September 2015.

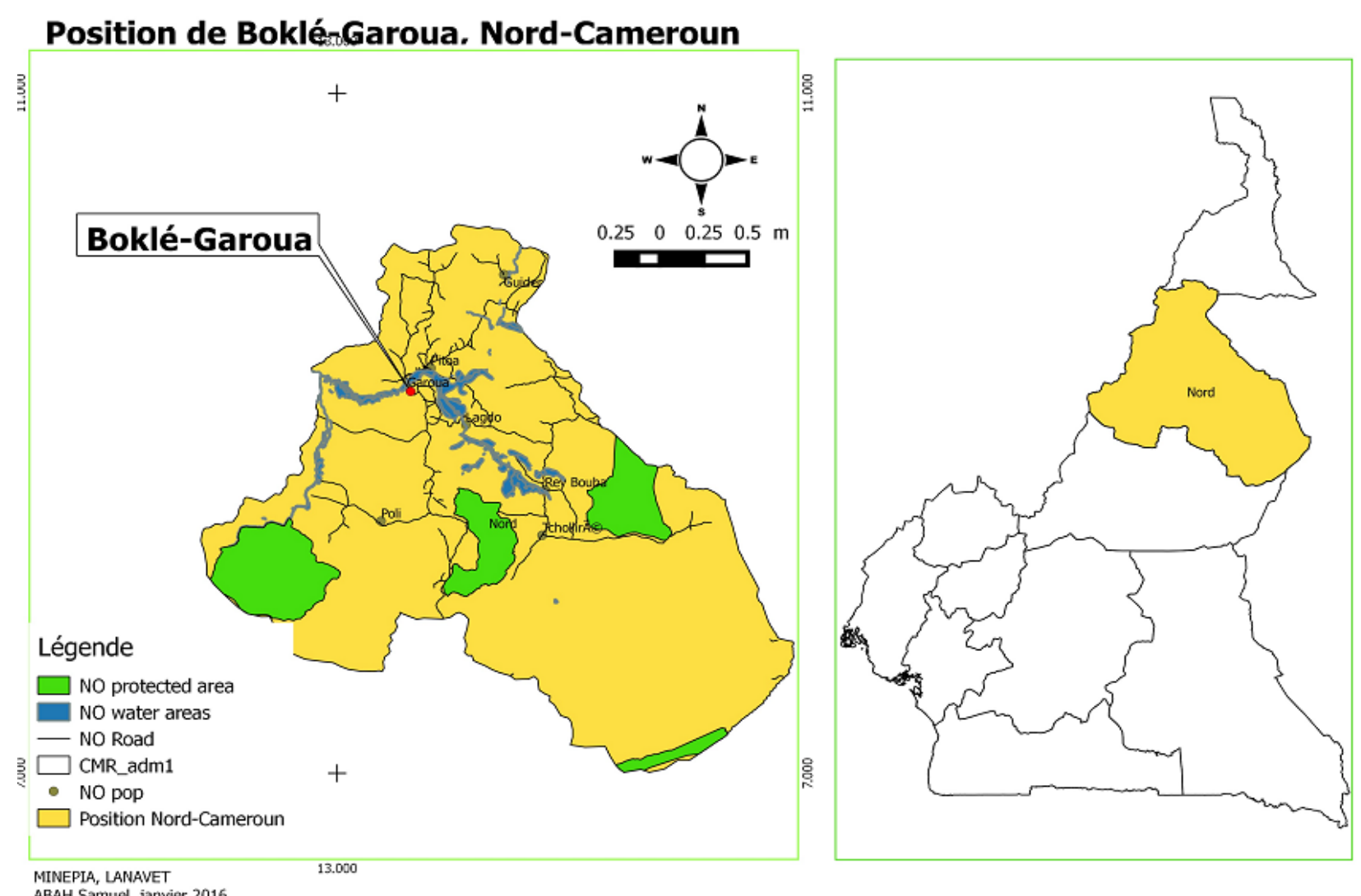

Fig.1: Location of the study area (red star). 


\section{Tick collection and identification}

Six cattle were used for this study.Tick collection was carried out using blunt steel forceps andthorough examination of the entire body surface of the restrained animal was carried out. Ticks were preserved in tubes containing $70 \%$ ethanol. In the parasitology laboratory of the LANAVET, all collected ticks were counted and identified upto species level using a dissecting microscope and following published keys (Walker et al., 2003; Bouattour, 2002).

\section{Blood collection and haematocrit determination}

Blood was collected from cattle via the jugular vein during the tick collection days. Blood in the capillary tubes were sealed with 'cristoseal' (Hawksley) and centrifuged immediately in a microhaematocrit centrifuge for 5minutes at 90oorevolutions per minute. After centrifugation, the haematocrit was determined using a haematocrit reader.

\section{Statistical analysis}

The SPSS (version 17.0) software was used for analysis. The mean number of the tick species with respect to month was compared using one way ANOVA and post hoc turkey test was used to compare the difference between the means. The mean tick number was correlated with mean haematocrit using the Pearson's correlation test. All statistical tests were kept at $\mathrm{p}<0.05$ significance level.

\section{Results}

In total, 404 ticks were collected from May to September 2015, identifiedand classified under four species notably A. variegatum, $H$. truncatum, $R$. sanguineus and $R .(B$.$) decoloratus (Fig. 2$ \& Table 1). H. truncatum(5\%) was the most frequent species and $R$. sanguineus(1\%)was least represented (Table 1). It was noticed that more males were collected than females, but this was different for $R$. (B.) decoloratus where more females were encountered as compared to their male counterparts (Table 1 ).

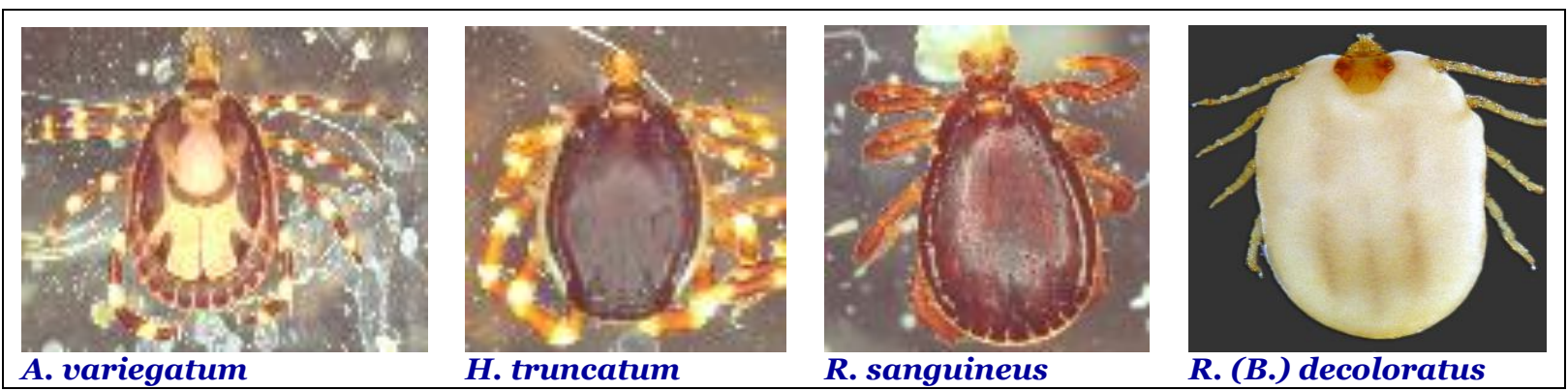

Fig. 2: Different species of ticks collected from the study area.

Table 1. Tick species collected with respect to sex.

\begin{tabular}{lllll}
\hline Tick species & Male & Female & Total & Frequency (\%) \\
\hline A. variegatum & 142 & 32 & 174 & 43 \\
H. truncatum & 155 & 49 & 204 & 50 \\
R. sanguineus & 1 & 1 & 2 & 1 \\
R. (B.) decoloratus & 1 & 23 & 24 & 6 \\
Total & $\mathbf{2 9 9}$ & $\mathbf{1 0 5}$ & $\mathbf{4 0 4}$ & $\mathbf{1 0 0}$ \\
\hline
\end{tabular}

Based on the mean number of ticks collected with respect to survey month, the highest was observed in June and lowest in May. All species were present during prospection months except Rhipicephalus sanguineus that was only present in May (Table 2). The mean number of $A$. variegatum, $H$. truncatum and $R$. (B.) decoloratus did not differ across seasons and species. But, $R$. sanguineus showed a statistically significant difference with mean number in May as compared to the other collection months (Table 2). There was a negative and non significant correlation between mean haematocrit and mean tick number (Fig.3). 
Table 2. Mean number of ticks collected with respect to prospection month.

\begin{tabular}{|c|c|c|c|c|}
\hline \multirow{2}{*}{ Month } & \multicolumn{4}{|c|}{ Mean tick species \pm standard deviation } \\
\hline & A. variegatum & H. truncatum & R. sanguineus & R. (B.) decoloratus \\
\hline May & $1.17 \pm 1.52^{\mathrm{a}}$ & $0.92 \pm 1.3^{\mathrm{a}}$ & $0.17 \pm 0.39^{\mathrm{a}}$ & $0.67 \pm 0.89^{a}$ \\
\hline June & $1.77 \pm 1.98^{\mathrm{a}}$ & $1.31 \pm 3 \cdot 30^{\mathrm{a}}$ & $0.00 \pm 0.00^{b}$ & $0.04 \pm 0.20^{\mathrm{a}}$ \\
\hline July & $1.17 \pm 2.36^{\mathrm{a}}$ & $0.58 \pm 1.36^{\mathrm{a}}$ & $0.00 \pm 0.00^{b}$ & $0.11 \pm 0.40^{\mathrm{a}}$ \\
\hline August & $0.42 \pm 0.94^{\mathrm{a}}$ & $1.17 \pm 2.18 \mathrm{a}$ & $0.00 \pm 0.00^{b}$ & $0.04 \pm 0.20^{\mathrm{a}}$ \\
\hline September & $0.02 \pm 0.14^{\mathrm{a}}$ & $1.10 \pm 2.34^{\mathrm{a}}$ & $0.00 \pm 0.00^{b}$ & $0.17 \pm 0.56^{a}$ \\
\hline
\end{tabular}

Similar supersript letters across columns and rows indicate a non-statistically significant difference ( $p>0.05)$, while different superscript letters across columns and rows indicate a statistically significant difference $(\mathrm{p}<0.05)$.

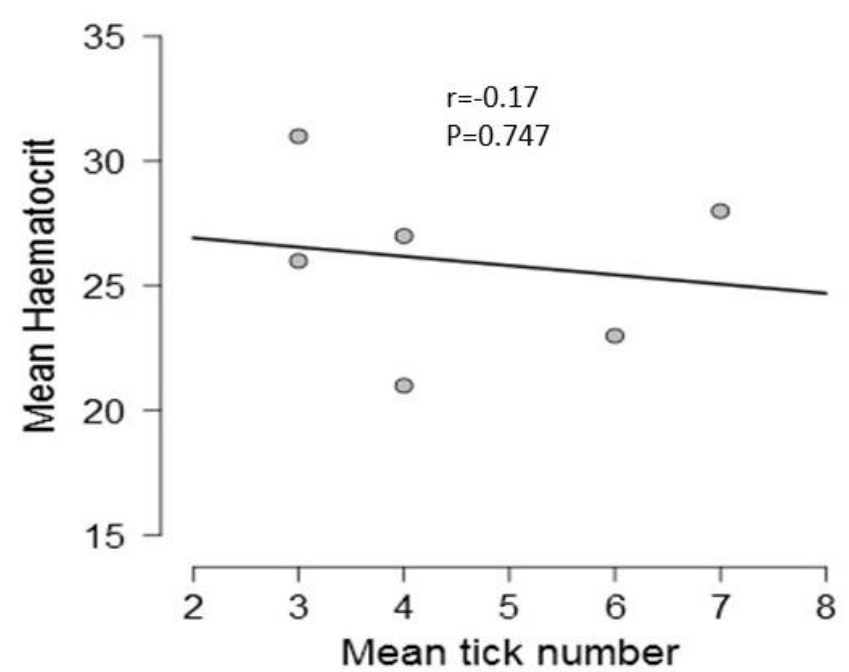

Fig. 3: Correlation between mean haematocrit and mean tick number.

\section{Discussion}

The present prospection led to the identification of four species of ticks with $H$. truncatum being the most prevalent of the species encountered. Similar work conducted in Cameroon (Awa et al., 2015; Mamoudou et al., 2015) indicate a low representation of $H$. truncatum and lack of Boophilus decoloratus. The number of species encountered in this study are more than those reported by Abah et al. (2017) in the same study area. This could be related to the difference in the study duration in the different studies; as the present study was carried out in five different months while that of Abah et al. (2017) was conducted in one month, indicating a greater chance of encountering higher species in the former than in the latter. The high prevalence of $H$. truncatum in the present collection was contrary to the reports from the same and neighbouring regions of Cameroon (Mebanga Sassa et al., 2014; Mamoudou et al., 2016). The high number of this species could be related to the prevailing favourable conditions for this species during the collection months. However, Dobler-Chitimia et al. (2019) reported that the genus Hyalomma is wide spread in Africa. The high prevalence range of ticks on animals during survey was not astonishing because the study was carried out in the rainy season and this season has been reported to favour tick development and survival in several regions of Africa (Mebanga Sassa et al., 2014). High encounter rate was obtained for male ticks than their female counterparts. The gender difference obtained in the present study is contrary to that obtained in studies from Cameroon and elsewhere (Mamoudou et al., 2016; Behroz Davari et al., 2017; Diaha-Kouame et al., 2019). The high population of males was from $H$. truncatum and $A$. variegatum whose population constituted $93 \%$ of the ticks collected, indicating that more males for the two species emerged and survived than their female counterparts. The low number of ticks caught during rainy season which happens to be the season that favours tick development could be explained by the fact that the collection was carried out from experimental cattle kept in a semiintensive management system. According to Mebanga Sassa et al. (2014) and Abah et al. (2017), ticks are highly encountered on cattle in extensive husbandry system than on those in the semiintensive system. The discrepancy in tick collection with respect to husbandry system can be related to the fact that cattle in the extensive system graze freely and are highly exposed to ticks on pasture surface that they share with infested cattle while those in the semi-intensive system are confined, do not graze freely, and less in-contact with infested animals. There was a negative and non-significant correlation between mean haematocrit and mean tick load. This finding is similar to that obtained by Mamoudou et al. (2015); Abdoulmoumini et al. (2017) who propounded that ticks and co-infection 
with TBDs and trypanosomes negatively affected the packed red blood cell volume of cattle. Because the decrease in haematocrit is caused by several factors, tick presence alone without considering the impact of other pathogens and environmental factors will not be sufficient to account for this phenomenon. Despite the high usage of acaricides by herders in the North region of Cameroon, ticks still remain a major problem to them since their occurrence causes production losses and high cost for their control.

\section{Conclusion}

This propspection led to the identification of four species of ticks notably $A$. variegatum, $H$. truncatum, $R$. sanguineus and $R$.(B.) decoloratus. $H$. truncatumwas most frequent and important tick species during the study period. There was a negative and non-significant difference between tick number and haematocrit.

\section{Acknowledgement}

Authors are grateful to all the staff of the LANAVET who took part in this survey. We thank the staff of FLI: Pr Martin Groschup, Claudia, Dr. Marc Marten, Dr. Dorothee, Isholde Shuster, Juan, Melanie and Miriam for their valuable contributions.

\section{Conflict of interest statement}

Authors declare that they have no conflict of interest.

\section{References}

Abah, S., Njangloga, A.M., Zoli, A.P., Mamoudou, A., Sevidzem, S.L., Souley, A., Aboubakar, Y., Dickmu, S., Stephen., Tchuinkam, T., 2017. Commercial acaricides in pour-on formulation react differently in reducing tick numbers on cattle in extensive and intensive management systems in Bockle, North Cameroon. Direct Res. J. Agric. Food Sci. 5(5), 232-238.

Abdoulmoumini, M., Cyril, N., lendzele, S., Kingsley, M., Njongui, J., Pagnah, Z., 2017. Bovine babesiosis and anaplasmosis in some cattle farms in the Vina Division. Int. J.
Livestock Res. 7(6), 69-80.

Awa, D.N., Adakal, H., Luogbou, N.D.D., Wachong, K.H., Leinyuy, I., Achukwi, M.D., 2015. Cattle ticks in Cameroon: Is Rhipicephalus (Boophilus) microplus absent in Cameroon and the Central African region? Ticks Tick. Dis. 6, 117-122.

Behroz, D., Firoz, N.A., Hassan, N., Mansour, N., Mohammad, A., Aref, S., 2017. Seasonal distribution and faunistic of ticks in the Alashtar county (Lorestan Province), Iran. Pan Afr. Med. J. 27, 284.

Bouattour A., 2002. Clé dichotomique et identification des tiques (Acari: Ixodidae) parasites du bétail au Maghreb, 43-49.

de la Fuente, J., Almazan, C., Canales, M., Perez de la, L.J.M., Kocan, K.M., Willadsen, P., 2007. A ten-year review of commercial vaccine performance for control of tick infestations on cattle. Anim. Health Res. Rev. 8, 23-28.

Diaha-Kouame, C.A., Yao, K.P., Diobo, N.F., Silue, G.U., Sevidzem, S.L., Acapovi-Yao, G.L., 2019. Infestation of ruminant species by ticks and lice in Port-Bouët cattle market (Abidjan- Cote D’ivoire). Arch. Vet. Anim. Sci. 1(1), 2-7.

Lew-Tabor, A.E., Rodriguez, V.M., 2016. A review of reverse vaccinology approaches for the development of vaccines against ticks and tick borne diseases. Ticks Tick. Dis. 7, 573-585.

Mamoudou, A., Nguetoum, N.C., Zoli, P.A., Sevidzem, S.L., 2016. Identification and infestation of ticks on cattle in the peri-urban area of Ngaoundere, Cameroon. J. Vet. Sci. Med Diagn. 5, 4.

Mamoudou, A., Suh, P.F., Jean, E.N., 2015. Impact of tick infestation and trypanosomiasis in cattle in the Sudano-Sahelian Zone of Cameroon. J. Vet. Adv. 5(5), 919-924.

Mebanga Sassa, A., Agnem, E.C., Gambo, H., Njan Nloga, A., 2014. Inventaire et prévalence des tiques du bétail dans les élevages de l'Adamaoua au Cameroun. Rev. Afr. Santé Pdn. Anim. 12 (1), 15-19.

Ministère de l'Elevage, des Pêches ET des Industries Animales (MINEPIA), 2003. Rapport d'activité, 159.

Silatsa, B.A., Kuiate, J.R., Njiokou, F., Simo, G., Feussome, J.M., Alabi, T., Gaston, S.A., Bernard, B., Richard, B., Naftaly, G., Opiyoi, S.O., Djikenga, A., Pelle, R., 2019. A country wide molecular survey leads to a seminal identification of the invasive cattle tick 
Rhipicephalus (Boophilus) microplus in Cameroon, a decade after it was reported in Coted'Ivoire. Ticks Tick. Dis. 10, 585-593.

Walker, A.R., Bouatour A., Camicas, J.L., Estrada-

Pena, A., Horak, I.G., Latif, A.A., Pegram, R.G., Preston, P.M., 2003.Ticks of domestic animals in Africa: a guide to identification of species,
Bioscience Reports, Edinburgh Scotland, U.K. pp.47-221.

Yao-Acapovi, G.L, Mavoungou, J.F., Sevidzem, S.L., 2018. Tick population on large and small ruminant species in the Port-Bouët cattle market in Abidjan, Ivory Coast. Livestock Res. Rural Develop. 30(6), 1-11.

\section{How to cite this article:}

Abah, S., Abel, W., Njan Nlôga, A. M., Lendzele, S. S., Mamoudou, A., Dickmu, S., Poueme Namegni, R. S., Aboubakar, Y., Zoli, A., Christian, N., Souley, A., 2019. Tick infestation and haematocrit alteration of cattle in Boklé-Garoua (Northern Cameroon). Int. J. Curr. Res. Biosci. Plant Biol. 6(11), 29-34.

doi: https://doi.org/10.20546/ijcrbp.2019.611.004 